\title{
Effects of Dietary Inclusion with 3\% Camel Fat and 3\% Sheep Fat on Broilers Blood Parameters and Serum Cholesterol
}

\author{
Badea Ali Gaffer ${ }^{1}$, Mohamed Tag Eldin Ibrahim², Omer Massaad Elbashier ${ }^{3}$ \\ ${ }^{1,2,3}$ Sudan University of and Technology
}

\begin{abstract}
This study was performed to investigate the effect of Inclusion of 3\% sheep and camel fat on serum cholesterol and blood parameters of broilers, including red blood cell count (RBC), haemoglobin concentration (Hb), leucocytes counts (WBC), mean corpuscular haemoglobin (MCH)) and derived (i.e. mean corpuscular heamoglobin concentration (MCHC)) values. Three hundred unsexed broiler chicks, 28 day-old (Ross 308) were used. The Chicks were randomly distributed into 3 treatments experimental groups, designated T1, T2 and T3, each group has 4 replicates of 25 chicks. Birds were fed experimental diets for 3 weeks. They were fed finisher diets from 29 to 49 day old, in which sheep and camel fat was added to the iso-calaric and iso-nitrogenous diet 0\% (Control group), 3\% in each experimental T1, T2 and T3. Boilers fed sheep and camel fat added to their diets, scored highly significant differences ( $\mathbf{p}<0.01$ ) on blood parameters, Hemoglobin concentration (Hb g/dl), Packed cell volume(PCV\%), White blood cell count $\left(\mathrm{WBC} 10^{3} / \mathrm{ml}\right)$, Red blood cell count $\left(\mathrm{RBC} 10^{6} / \mathrm{ml}\right)$ and Mean cell hemoglobin concentration, compared to those fed the control diet

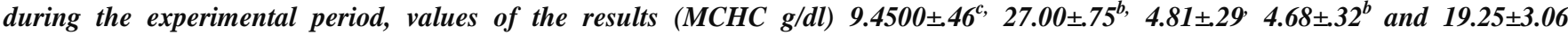
respectively. Mean cell volume (MCV FL) showed significant differences $(p<0.05)$ for boilers fed sheep and camel fat compared to those fed the control diet. No significant differences were noticed among T1, T2 and T3 for mean cell hemoglobin (MCH pg.). The highest HB results were observed in chicks fed on sheep fat based diet and the highest MCV was observed in chicks fed on control diet during the experimental period. Serum cholesterol scored highly significant differences $(p<0.01)$ for sheep and camel fat.
\end{abstract}

Keywords: Poultry, Broilers, Nutrition, Blood parameters, Haemoglobin

\section{Introduction}

Birds are homeotherms (warm-blooded studies on haematological parameters give a good understanding of the nutritional status of the feed fed to poultry. It also provides useful information on the metabolic profile, which is used to assess the bird's state of health [20]. Broilers fed with sunflower oil alone and mixture of sunflower oil and tallow had significantly $(\mathrm{P}<0.01)$ lower total serum and meat cholesterol level.[9].

Blood is vital to life and before any meaningful work can be done on the biology of birds, detailed haematolgical study is imperative. This is because any abnormal variation in haematology impairs the primary physiological functions of the body. Studies on haematological parameters give a good understanding of the nutritional status of the feed fed to poultry. It also provides useful information on the metabolic profile, which is used to assess the bird's state of health [5] and [20]. Commonly used haematological parameters measured during blood studies include red blood cell count (RBC), haemoglobin concentration (Hb), leucocytes counts (WBC), erythrocyte; absolute (i.e. mean corpuscular haemoglobin (MCH)) and derived (i.e. mean corpuscular heamoglobin concentration (MCHC)) values.

There is a direct relationship between quality of feed ingested and the blood composition of broilers. Significantly higher values of red blood cells, Hb and PCV were recorded in broilers fed high protein diets than those fed low protein [12].Macrocytic condition of erythrocytes for mean cell haemoglobin (MCH), mean cell haemoglobin concentration (MCHC) and mean corpurscular volume (MCV) were reported to be within the ranges of 33 to 47 (pg), 26 to 35 (g/dl) and 90 to140 (fl), respectively. Dietary differences affect erythrocyte values among group of animals [1]. It has been shown that rats fed restricted diets had lower PCV values than those fed the same diets ad-libitum. Retention of energy intake was also shown to be associated with relative elevation of MCHC values [19], reported that $\mathrm{Hb}$ concentration, PCV and MCHC, are very sensitive to the level of protein intake by poultry. There is a direct relationship between quality of feed ingested and the blood composition of broilers. Fats provide varying quantities of the essential nutrient linoleic acid [11].Another important role of fats in diet is its inhibition from de novo lipogenesis in broiler chickens that could increase energy efficiency in diets. The profile of fatty acids is of importance to the quality of the utilization of lipids and to the absorption of these lipids by the bird [25].

Fats and oils are subject to oxidation which is responsible for the development of rancidity. Rancid fat products have an objectionable odour and decrease the palatability of a feed. Rancidity can be prevented or slowed by adding antioxidants like Vitamin E. When commercial feed fats are used to increase energy in feedlot diets they are usually added at the rate of 2 to 5 percent of the diet's total dry matter.[14] and [18], reported that house temperature: Probably the most important factor influencing feed conversion is the temperature of the broilers environment.

The addition of fat to diets, besides supplying energy, improves the absorption of fat-soluble vitamins and provides varying quantities of the essential fatty acids, diminishes the dustiness, increases the palatability of the rations and improves the energy efficiency [2],[3] and [16[.Furthermore, it reduces the passage rate of the digest $a$ in the 


\section{International Journal of Science and Research (IJSR) \\ ISSN (Online): 2319-7064 \\ Index Copernicus Value (2013): 6.14 | Impact Factor (2015): 6.391}

gastrointestinal tract, which allows a better absorption of all diet nutrients [13]. Fats or oils as energy rich feeds are available from animal sources such as beef, sheep, camel and fish oil or from plant sources such as soyabean, sunflower and maize oil. In diets with similar nutritive value, chickens fed with rations containing oil showed better performance than birds fed diets without oil inclusion [17].
Cholesterol is an essential part of cells in the body and is used to make certain hormones and digest fats. In an experiment the response in cholesterol and glucose (GLU) concentrations differed significantly between fat sources with serum cholesterol concentration increasing and serum GLU decreasing at a faster rate when beef tallow was added than with soyabean oil. In other studies, broilers fed diets rich in cholesterol or SFA had higher carcass and blood cholesterol levels [23]. For example, [7], found that serum cholesterol concentration of chicks was not affected by different fat sources. Generally, SFA increases serumlow density lipoprotein(LDL) value while dietary polyunsaturated fatty acid PUFA decrease serum very low density lipoprotein (VLD), LDL and GUL and increase high density lipoprotein (HDL) values in comparison with saturated fatty acid(SFA)[8].

\begin{tabular}{|c|c|c|c|}
\hline \multicolumn{2}{|c|}{ Table (1)Camel fat fatty acids Profile } & Sheeo fat fatty acids Profile & $\%$ \\
\hline \multirow{11}{*}{$\begin{array}{c}\text { Myristic } \\
\text { Palmitic } \\
\text { Stearic } \\
\text { Arachidic } \\
\text { Tetradecenoic } \\
\text { Hexadecenoic } \\
\text { Octadecenoic } \\
\text { Octadecadienoic } \\
\text { Octadecatrienoic } \\
\text { Aseicosenoict } \\
\text { Unsaponifiable }\end{array}$} & \multirow{11}{*}{$\begin{array}{c}6-25 \\
28-6 \\
27-36 \\
1-54 \\
0-54 \\
3-19 \\
26-30 \\
1-86 \\
0-92 \\
3-01 \\
0-34\end{array}$} & \multirow{11}{*}{$\begin{array}{c}\text { Myristic Palmitic } \\
\text { Stearic } \\
\text { Arachidic } \\
\text { Tetradecenoic } \\
\text { HexadecenoicOctadecenoic } \\
\text { OctadecadienoicOctadecatrienoic C2022 } \\
\text { unsaturated acids }\end{array}$} & $2-4$ \\
\hline & & & $23-28$ \\
\hline & & & $15-31$ \\
\hline & & & ---- \\
\hline & & & ------ \\
\hline & & & $1-0-2-5$ \\
\hline & & & $36-46$ \\
\hline & & & $\begin{array}{l}30-40 \\
-4-6\end{array}$ \\
\hline & & & $\begin{array}{l}-4-0 \\
----\end{array}$ \\
\hline & & & $0.5^{*}$ \\
\hline & & & \\
\hline & & quoted are \% by wt.) & \\
\hline
\end{tabular}

\section{Materials and Methods}

\section{Experimental location and Site}

This study was conducted at the Poultry Farm, College of Animal Production Science and Technology, Sudan University of Science and Technology during the period from $2^{\text {Its }}$ of March to 9 of April 2015. This study was performed to investigate the effect of Inclusion of 3\% sheep and camel fat on serum cholesterol and blood parameters of broilers, including red blood cell count (RBC), haemoglobin concentration (Hb), leucocytes counts (WBC), mean corpuscular haemoglobin (MCH)) and derived (i.e. mean corpuscular heamoglobin concentration (MCHC)) values.

\section{Experimental houses}

The experiment was conducted in an open side deep litter house $8 \times 5 \mathrm{~m}$ dimensions, $4 \mathrm{~m}$ central altitude and $2.5 \mathrm{~m}$ side altitude, constructed by corrugated iron sheets roofing, wire netting sheets supported by $50 \mathrm{~cm}$ cement wall at sides and concrete floor. The long axis of the house extended eastwest facing the wind direction for efficient ventilation. The house was divided into twelve experimental sections (replicates) of equal area $\left(1.5 \mathrm{~m}^{2}\right)$, which separate experimental sections. The experimental house and equipments were cleaned, burned and disinfected. Then fresh wood shaving litters was spread in the experimental section floor at depth of $5 \mathrm{~cm}$, Moreover, each section was provided with one tubular metal feeder and circular plastic drinker. The house had four lamps at $2 \mathrm{~m}$ altitude,expressed as high from ground.

\section{Experimental birds}

300 unsexed broiler chicks, 28 day-old (Ross 308) were used. The Chicks were randomly distributed into 3 experimental groups, designated T1, T2 and T3, each group has 4 replicates of 25 chicks. Birds were fed finisher diets from 29 to 49 day old, in which sheep fat was added to the iso-calaric and iso-nitrogenous diet 0\% T1 (Control group), $3 \%$ in each diet T2 andT3. Red blood cell count (RBC), haemoglobin concentration (Hb), leucocytes counts (WBC), erythrocyte; absolute (i.e. mean corpuscular haemoglobin $(\mathrm{MCH})$ ) and derived (i.e. mean corpuscular heamoglobin concentration (MCHC)) and mortality. Water was supplemented with multi -vitamin from 28 -31 days. Antibiotic Doxystin (Doxycycline Hcl 50mg colistinsulphate 400000 I.U) as prevention dose from 35 40 day.

\section{Experimental Diets}

The experiment consisted of three treatment groups, designated as $\mathrm{T} 1$ control group fed0\% fat,T2 fed 3\% sheep fat and T3 fed camel 3\%. Each group consists of one hundred birds and each group was further subdivided into four replicates of twenty five per replicate. All birds were fed on pre starter ration for the $1^{\text {st }}$ week of age then they were fed on starter feed ration form (day 8to27 day). Then birds were allocated in to the experimental finisher diets form (28 day- 49 day). All rations were formulated to be approximately iso-caloric and iso-nitrogenous to meet the nutrient requirements for broiler chicks as out lined by the National Research Council [15]. Feed and water were supplied adlibitum during the experimental periods. 


\section{International Journal of Science and Research (IJSR) \\ ISSN (Online): 2319-7064}

Index Copernicus Value (2013): 6.14 | Impact Factor (2015): 6.391

Analysis of the finisher experimental ration:

Table 2: Composition (\%) and calculated analysis of experimental finisher diets:

\begin{tabular}{|c|c|c|c|}
\hline $\begin{array}{l}\text { Treatment } \\
\text { Ingredients } \%\end{array}$ & $\mathrm{~T} 1$ & $\mathrm{~T} 2$ & T3 \\
\hline Sorghum grains & 74.7 & 48.7 & 48.7 \\
\hline Wheat bran & 0.1 & 1.9 & 1.9 \\
\hline G.N.C & 18.46 & 39.8 & 39.8 \\
\hline Lime stone & 0.74 & 0.85 & 0.85 \\
\hline D.C.P & 0.57 & 0.29 & 0.29 \\
\hline lysine & 0.43 & 0.3 & 0.3 \\
\hline Methionine & 0.05 & 0.05 & 0.05 \\
\hline Common Salt & 0.01 & 0.1 & 0.1 \\
\hline Super Concentrate & 5 & 5 & 5 \\
\hline Fat & 0 & 3 sheep & 3 camel \\
\hline \multicolumn{4}{|c|}{ Calculated analysis } \\
\hline Premix & 0.01 & 0.01 & 0.01 \\
\hline $\mathrm{ME}(\mathrm{Mj} / \mathrm{kg})$ & 13.39 & 13.39 & 13.39 \\
\hline $\mathrm{CP} \%$ & 20.01 & 20 & 20 \\
\hline CF\% & 3.21 & 3.61 & 3.61 \\
\hline $\mathrm{Ca} \%$ & 1 & 1.01 & 1.01 \\
\hline Av.p\% & 0.44 & 0.45 & 0.45 \\
\hline Lysine\% & 0.93 & 1.11 & 1.11 \\
\hline Methionine\% & 0.50 & 0.51 & 0.51 \\
\hline
\end{tabular}

[27]

Table (3): Chemical composition of concentrate

\begin{tabular}{|c|c|c|c|c|c|c|c|}
\hline Item & $\mathrm{ME}$ & $\mathrm{CP}$ & $\mathrm{Ca}$ & $\mathrm{AV} . \mathrm{P}$ & Lysine & Methionine & $\mathrm{CF}$ \\
Ingredients & $\mathrm{Mj} / \mathrm{kg}$ & $\%$ & $\%$ & $\%$ & $\%$ & $\%$ & $\%$ \\
\hline Concentrate & $\mathbf{1 0 . 0 2}$ & $\mathbf{3 5}$ & $\mathbf{1 0 . 6}$ & $\mathbf{4 . 9}$ & $\mathbf{1 . 1}$ & $\mathbf{4 . 3}$ & $\mathbf{1 . 5}$ \\
\hline
\end{tabular}

Source: [26]

\section{Blood Sampling}

Before slaughtering birds were fasted for 12 hours. Two birds were randomly selected from each replicate (8bird's/treatment) for blood samples.

Blood samples were collected from the jugular vein, received in a labeled test tubes, contains an anti-coagulant (EDTA).Tubes were placed horizontally on racks at room temperature. Blood serum was separated by centrifugation.

Hemoglobin (HB), packed cell volume (PCV), and red white blood cell count were determined. Determination of hemoglobin content was carried according to [22], packed cell volume was done according to [21]. Red blood cell (RBC) count and total levkocyte count (TLC) were done according to routine clinical methods. These values were utilized for calculating mean corpuscular hemoglobin concentration (MCHC) according [4], as described below:-

Mean Cell Volume (f1) $=$ Packed Cell Volume $/ \mathrm{dI} * 10 /$ $\mathrm{RBC} / \mathrm{MB}\left(10^{\mathrm{N}}\right)$

Mean Cell Hemoglobin (Pg) = Packed Cell Volume / dI*10 / $\mathrm{RBC} / / \mathrm{N}^{\mathrm{L}}{ }_{10}^{\mathrm{N}}$
Mean Cell Hemoglobin Concentration $=(\mathrm{g} / \mathrm{dI} * 100 / \mathrm{BCV}$ (\%)

Deice and Lewis (1977) .Manual procedure of serum:

500 - $550 \mathrm{~nm}$ Wavelength

$1 \mathrm{~cm}$ light pa Cuvette

Temperature 20 - 25 or 37c`

Zero adjustment against reagent blank

Specimen serum or plasma

Samples were mixed, incubated for 5 minutes at 37c or minutes at 20-25 c. he absorbance of specimen measured $t$ $\left(\begin{array}{c}\mathrm{A} \\ \text { specimen }\end{array}\right)$ and standard $\left({ }^{\mathrm{A}}{ }_{\text {standard }}\right)$ against reagent blank. The color is stable for 60 minutes.

\section{Statistical Analysis}

Completely randomized design (CRD) was used in the current The data were subjected to analysis of variance (independent t-test ) and the means were suprate by the least significant difference (LSD) using the statistical package of social science (SPSS) version 16.0 (2007) computer program. A probability of $(\mathrm{p} \leq 0.05)$ was required for statements of significance. . 


\section{International Journal of Science and Research (IJSR) ISSN (Online): 2319-7064}

Index Copernicus Value (2013): 6.14 | Impact Factor (2015): 6.391

\section{Results}

\begin{tabular}{|c|c|c|c|c|c|c|c|}
\hline \multicolumn{8}{|c|}{ Table(4) :Dietary (Finisher) effects of sheep and camel fat on broiler Blood analysis: } \\
\hline $\begin{array}{ll}\text { Treatment } & \text { Item } \\
\end{array}$ & $\mathrm{Hb} \mathrm{g} / \mathrm{dL}$ & PCV\% & WBC & RPC & $\mathrm{MCV}$ & $\mathrm{MCH}$ & MCHC \\
\hline Control T1 & $9.4500 \pm .46^{\mathrm{c}}$ & $27.0000 \pm .75^{\mathrm{b}}$ & $4.8125 \pm .29^{\mathrm{b}}$ & $4.6825 \pm .32^{\mathrm{b}}$ & $50.1050 \pm 4.83^{\mathrm{a}}$ & $19.2625 \pm 3.06$ & $.3475 \pm .01^{\mathrm{b}}$ \\
\hline Ration added sheep fatT2 & $13.3625 \pm .87^{\mathrm{a}}$ & $29.2500 \pm 1.00^{\mathrm{a}}$ & $7.1625 \pm .49^{\mathrm{a}}$ & $5.7537 \pm .53^{\mathrm{a}}$ & $51.3250 \pm 4.87^{\mathrm{b}}$ & $23.4650 \pm 2.87$ & $.4575 \pm .02^{\mathrm{a}}$ \\
\hline Ration added camel fatT3 & $12.1000 \pm .89^{\mathrm{b}}$ & $31.6250 \pm 1.49^{b}$ & $7.3250 \pm .68^{\mathrm{a}}$ & $5.3762 \pm .51489^{\mathrm{a}}$ & $51.6500 \pm 3.23^{b}$ & $19.9787 \pm 8.17$ & $.4375 \pm .032^{\mathrm{a}}$ \\
\hline Significance & $* *$ & $* *$ & $* *$ & $* *$ & $*$ & NS & $* *$ \\
\hline $\begin{array}{l}\text { *, means within the same } \\
\text { *: significance different at } \\
\text { **: Highly significance di } \\
\text { NS: No significant differe }\end{array}$ & $\begin{array}{l}\text { mn follon } \\
.05) \text {. } \\
\text { at at }(p<0 \text {. }\end{array}$ & & & & 0.05 & & \\
\hline
\end{tabular}

Table 5: Dietary (Finisher) effects of sheep and camel fat on broiler Blood Cholesterol

\begin{tabular}{|l|c|c|}
\hline Treatment & Cholesterol & Significance \\
\hline Control T1 & $96.3625 \pm 6.39^{\mathrm{b}}$ & \\
\hline Ration added sheep fat T2 & $136.30 \pm 47.104^{\mathrm{a}}$ & $* *$ \\
\hline Ration added camel fat T3 & $133.80 \pm 21.70^{\mathrm{a}}$ & $* *$ \\
\hline
\end{tabular}

The results of the effect of feeding sheep, and camel fat added to diets on the serum cholesterol and blood parameters are presented in tables (4) (5), Hemoglobin(Hb $\mathrm{g} / \mathrm{dl})$, Packed cell volume(PCV\%), White blood cell count $\left(\mathrm{WBC} 10^{3} / \mathrm{ml}\right)$, Red blood cell count $\left(\mathrm{RBC} 10^{6} / \mathrm{ml}\right)$ and Mean cell hemoglobin concentration (MCHC g/dl) showed highly significant differences $(\mathrm{p}<0.01)$. Mean cell volume (MCV $\mathrm{FL})$ showed significant differences $(\mathrm{p}<0.05)$. No significant differences were noticed for mean cell hemoglobin (MCH pg). Higher PCV, WBC, RBC and MCHC compared to those fed sheep and camel fat based diet and the control diet during the experimental period. The highest HB was observed in chicks fed on sheep fat based diet and the highest MCV was observed in chicks fed the control diet during the experimental period.

\section{Discussion}

This work was aimed to evaluate the effect of inclusion of two fat sources, sheep, and camel fat in the diets of broilers in the finisher phase, on serum cholesterol and haematological parameters.

The results of the effect of inclusion of 3\% sheep, and camel fat to diets of broilers, on serum cholesterol and blood parameters are presented in tables (4) and (5),Hemoglobin (Hb g/dl), Packed cell volume (PCV\%), White blood cell count $\left(\mathrm{WBC} 10^{3} / \mathrm{ml}\right)$, Red blood cell count $\left(\mathrm{RBC} 10^{6} / \mathrm{ml}\right)$ and Mean cell hemoglobin concentration (MCHC g/dl) showed highly significant differences $(\mathrm{p}<0.01)$, in chicks fed on sheep, and camel fat based diet, compared to birds fed the control diet during the experimental period while Mean cell volume (MCV FL) showed significant differences $(\mathrm{p}<0.05)$. No significant differences were observed for mean cell hemoglobin ( $\mathrm{MCH}$ pg). The highest $\mathrm{Hb}$ was observed in chicks fed on sheep fat based diet and the highest MCV was observed in chicks fed on control diet during the experimental period. Effects of dietary lipids on lipoprotein metabolism and some blood parameters have been extensively reviewed [8].
These high results could be due to the effect inclusion of fats in the diets, which besides supplying energy, improves the absorption of fat-soluble vitamins [3], provides varying quantities of the essential fatty acids, diminishes the dustiness, increases the palatability of the rations and improves the energy efficiency [3] and [16]. Furthermore, it reduces the passage rate of the digest a in the gastrointestinal tract, which allows a better absorption of all diet nutrients [13].

The results showed significant difference $(\mathrm{p}<0.05)$ in the serum cholesterol level (mg/dl) which increased by adding sheep and camel fat. The present study results are in agreement of that reported by [24], who reported that tallow produced a significant rise in serum cholesterol. These results may be explained on basis that the high SFAs and low PUFAs contents in camel and sheep fat, which is an important contributing factor to raising serum cholesterol level, however results of some studies do not agree with the findings of the present study. [7], found that serum cholesterol concentration of chicks was not affected by different fat sources. Effects of dietary lipids on lipoprotein metabolism and some blood parameters have been extensively reviewed. Generally, saturated fatty acid SFA increases serum LDL value while dietary unsaturated fatty acids PUFA decrease serum VLDL, LDL and cholesterol and increase HDL values in comparison with SFA [8].In this study cholesterol differed significantly between fat sources with serum cholesterol concentration increased when fat was added than with the control. In other studies, broilers fed diets rich in cholesterol or SFA had higher blood cholesterol levels [23], however results of some studies do not agree with the findings of present study. [6[, reported that the higher level of energy (3200Kcal ME/kg diet) induced a higher level of triglyceride and cholesterol. Soyabean oil would increase digestion and absorption and the biosynthesis of triglycerides in liver because of its unsaturated fatty acid content, thereby increasing the free fatty acid content in blood serum [10].

\section{References}

[1] Akpodiete, O. J and A. D. Ologhobo and (A. D. Ologhobo and E. A. Iyayi, Eds. The nutritive value of maggot meal in broiler chicks. II - Nutrient retention, haematology and serum chemistry. In: The Nigerian Livestock Industry in the 21st Century. Proceedings of the 3rd Annual Conference of the Animal Science 


\section{International Journal of Science and Research (IJSR) \\ ISSN (Online): 2319-7064 \\ Index Copernicus Value (2013): 6.14 | Impact Factor (2015): 6.391}

Association of Nigeria, 1998) held at Lagos Airport Hotel, Ikeja, and Lagos.

[2] Baião NC, Lara LJC. Oil and fat in broiler nutrition. Braz J Poult Sci. 2005; 1:129-141.

[3] Balevi, T. \&Co_kun, B. Effects of some oils used in broiler rations on performance and fatty acid compositions in abdominal fat. Rev. Méd. Vét. 2000, 151, 937-944.

[4] Dacie, SM Lewis; Investigation of the Megaloblastic anemias in practical hematology. (1971).

[5] Eggum, B. O. Indirect measures of protein adequacy. In: Protein Metabolismand Nutrition. (Coles, D. JA.,Rooman, K. N., Buttery, P. J., Lewis, D., Neals, R. J. and H. Swan, Eds.). Butterworths, Boston, London. 1976, P 249-257.

[6] Elmansy, M. M. Assessment of the effect of Lcarnitine supplementation to the diet with different dietary energy levels on broiler performance. M. Sc. Thesis, Fac. Agric., 2006, Tanta Univ., Tanta, Egypt.

[7] Fan, Q., J. Feng, S. Wu, K. Specht, and S. She. Nutritional evaluation of rice bran oil and a blend with corn oil. Nahrung 1995, 39:490-496.31.

[8] Grundy, B.M., Monounsaturated fatty acids, plasma cholesterol and coronary heart disease. Am. J. Clin. Nutr. 1989, 45, 1168-1175.

[9] Kannan Duraisamy, M. Senthilkumar, K. Mani. Effect of saturated and unsaturated fat on the performance, serum and meat cholesterol level in broilers Vet World. 2013; 6 (3): 159-162 doi: 10.5455/vetworld.2013, 159-162

[10] Lambourt, B. \&Jacquemin, C.,.Inhibition of epinephrine induced lipolysis in isolated white adipocytes of aging rabbits by increased alphaadrenegicresponsivenss. J. Lipid Res. 1979, 20, 208216.

[11] Leeson, S. and J.D. Summers,. Scoot's Nutrition of the Chicken. University Book. 2001, Guelph, Canada.

[12] Mitruka, B.M. and H.M. Rawnsley. Clinical, Biochemical and Haematological Reference Values in Normal Experimental Animals. Mason Publishing, New York, USA1977, pp: 53-54.

[13] Moav, R. Fat supplementation to poultry diet. WrldPoult. Misset. 1995, 11, 57-58.

[14] Nahashon, S. N.; Adefope, N.; Amenyenu, A. and Wright, D. Effects of dietary metabolizable energy and crude protein concentrations on growth performance and carcass characteristics of French guinea broilers. Poult. Sci., 2005, 84: 337-344.

[15] NCR. National Research Council. Nutrient Requirements of Poultry. 9th rev. ed. 1994, Natl. Acad. Press, Washington, DC.

[16] Nitsan, Z., Dvorin, A., Zoref, Z. \&Mokady, S. Effect of added soybean oil and dietary energy on metabolizable and net energy of broiler diets. Br. Poult. Sci. 1997, 38, 101-106. óleodissertação.

[17] Palmquist, D.L. An appraisal of fats and fatty acid. In: Poultry Feedstuff: Supply, Composition and Nutritive Value. 2002, Chapter 5, pp. 87-97.

[18] Sexana and Thacker PA, Campbell GL, XUY. Composition and nutritive value of acidulated fatty acids, degummed canola oil and tallow as energy sources for starting broiler chicks. Animal Feed and Technology1999; 46:251-260.
[19] Simarak, S., Chinrasri, O. and W. Aengwanich. Haematological, electrolyte and serum biochemical values of the Thai indeginous chickens (Gallusdomesticus) in northan Thailand.

[20] Songkalanakarin Journal of Science and Technology, 26(3): 425-430.

[21] Suchy, I. K. Haematological studies in adolescent breeding cocks. ACT VET BRNO, 2000; 69: 189-194.

[22] Strumia,M.M.,Sample,A.B.,and Hart,E.D..AmerJ.clin.Path., 1954 24, 1016.

[23] Van Kampen E.J. and W. G. Zijlstra. (1961). Standarizatio of haemoglobinometry. II. The haemoglobinocyanide method. Clin. Chem. Acta, 6: $538-544$

[24] Verma, N.D., Panda, J.N., Singh, K.B. \&Shrivastav, A.K.,. Effect of feeding cholesterol and fat on serum cholesterol of Japanese quail. Indian J. Poult. Sci. 1995, 30, 218-223.

[25] Wardlaw GM and Snook JT. Effect of diets high in butter, corn oil, or high-oleic acid sunflower oil on serum lipids and apolipoproteins in men. American Journal of Clinical Nutrition 1990; 51 (1) 815-821.

[26] Yeh, Y.Y. and G.A. Leveille. Studies on the relationship between lipogenesis and the level of coenzyme A derivatives, lactate and pyruvate in the liver of the growing chick. J. Nutr., 1971, 101: 911920.

[27] Lab of Hendrix Company,Netherlands

[28] Yousif G, Vandehaar MJ' Sharma BK, Herdt TH, Emery RS, Allen MS, Liesman JS. Effect of energy and protein density of prepartum diets on fat and protein metabolism of dairy cattle in the periparturientperiod.J Dairy Sci. 1999 Jun; 82(6):128295. 